\title{
Erratum to: The Impact of a Regular Blood Donation on the Hematology and EEG of Healthy Young Male Blood Donors
}

Mingxia Zhang • Gencang Zhang • Jie Yang • Andrew C. N. Chen

Published online: 31 December 2011

(C) Springer Science+Business Media, LLC 2011

Erratum to: Brain Topogr

DOI 10.1007/s10548-011-0203-0

Unfortunately, the third author's family name was misspelled in the online version of the article. The correct spelling is Jie Yang and not Jie Ynag.

The online version of the original article can be found under doi:10.1007/s10548-011-0203-0.

M. Zhang · J. Yang · A. C. N. Chen $(\bowtie)$

Center for Higher Brain Functions, Capital Medical University,

Beijing 100069, China

e-mail: ac@ccmu.edu.cn

G. Zhang

Linfen Blood Bank, Linfen 041000, Shanxi, China 